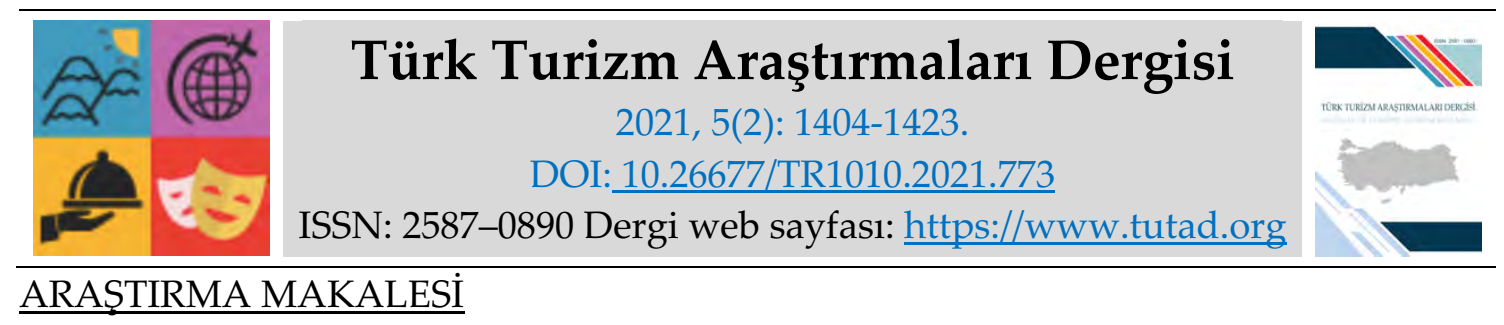

\title{
Turizm ve Otel İşletmeciliği Bölümü Önlisans Öğrencilerinin “Tatil” Kavramına İlişkin Algılarının Metaforlar Yardımıyla Analizi
}

Doç. Dr. Melike GÜL, Balıkesir Üniversitesi, Sındırgı MYO, Balıkesir, e-posta: melikegul@balikesir.edu.tr

ORCID: https://orcid.org/0000-0002-9046-4161

Doç. Dr. Kudret GÜL, Balıkesir Üniversitesi, Balıkesir MYO, Balıkesir, e-posta: kgul@balikesir.edu.tr

ORCID: https://orcid.org/0000-0002-9039-153X

Öz

Araştırmanın amacı, Turizm ve Otel İşletmeciliği bölümünde önlisans eğitimi alan öğrencilerin "tatil" kavramına ilişkin algılarının ortaya çıkartılmasıdır. Bu amaç doğrultusunda metafor analizine başvurulmuştur. Araştırmada her bir öğrencinin "tatil" kavramına yönelik birden fazla metafor üretmesine izin verilmiştir. Araştırmanın verileri, 2019-2020 eğitim-öğretim yılı bahar döneminde Balıkesir Üniversitesi Balıkesir Meslek Yüksekokulu ile Sındırgı Meslek Yüksekokulu Turizm ve Otel İşletmeciliği Bölümlerinin tüm sınıflarında öğrenim gören 140 öğrenciden elde edilmiştir. Bu araştırmada, nitel araştırma yöntemlerinden fenomenoloji deseni kullanılmıştır. Bulgular, yüzde ve frekans değerleri ile verilmiştir. Araştırma bulgularına göre önlisans öğrencileri "tatil" kavramına yönelik 180 metafor üretmişlerdir. Ancak anlamsız olduğu düşünülen toplam 10 metafor elenerek araştırmanın kapsamı dışında bırakılmış ve analizler 170 metafor üzerinden gerçekleştirilmiştir. Bu metaforlar 11 farklı kavramsal kategori altında toplanmıştır. Çalışmada "tatil" kavramına yönelik en fazla "dinlenme" metaforunun üretildiği belirlenmiştir.

Anahtar Kelimeler: Tatil, Metafor Analizi, Önlisans Öğrencisi, Turizm ve Otel İşletmeciliği Bölümü.

Makale Gönderme Tarihi: 24.02.2021

Makale Kabul Tarihi: 05.06.2021

\section{Önerilen Atıf:}

Gül, M. ve Gül, K. (2021). Turizm ve Otel İşletmeciliği Bölümü Önlisans Öğrencilerinin “Tatil” Kavramına İlişkin Algılarının Metaforlar Yardımıyla Analizi, Türk Turizm Araştırmaları Dergisi, 5(2): 1404-1423.

(C) 2021 Türk Turizm Araştırmaları Dergisi. 


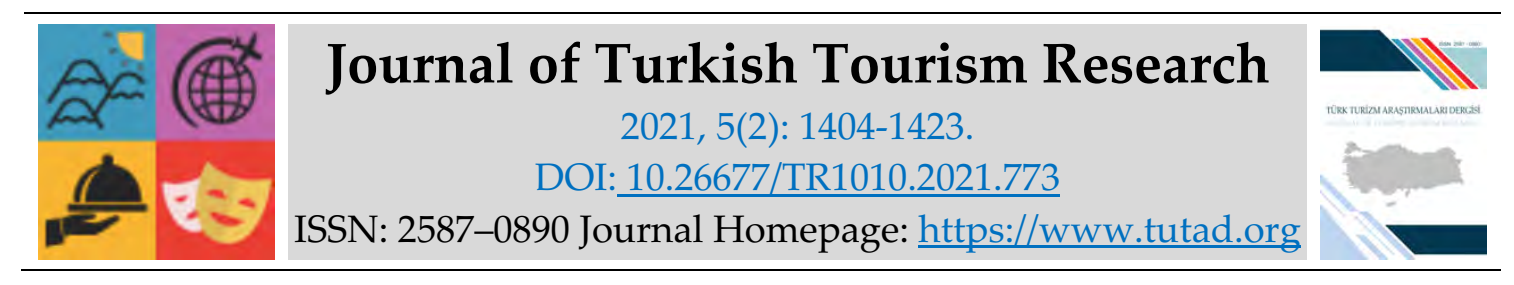

\title{
$\underline{\text { RESEARCH PAPER }}$
}

\section{Analysis of the Perception of Tourism and Hotel Management Associate Degree Students about the Concept of "Vacation" with the Metaphors}

Associate Prof. Dr. Melike GÜL, Balıkesir University, Sındırg1 Vocational School, Balıkesir, email: melikegul@balikesir.edu.tr

ORCID: https://orcid.org/0000-0002-9046-4161

Associate Prof. Dr. Kudret GÜL, Balıkesir University, Balıkesir Vocational School, Balıkesir, email: kgul@balikesir.edu.tr

ORCID: https://orcid.org/0000-0002-9039-153X

\begin{abstract}
The aim of the study is to reveal the perceptions of the students who receive associate degree in Tourism and Hotel Management about the concept of "vacation". Metaphor analysis was used in the study and each student was allowed to produce more than one metaphor for the "vacation concept". The data were obtained from 140 students who studying in the Tourism and Hotel Management Department at Balıkesir University Balıkesir Vocational School and Sindırg1 Vocational School in the spring semester of the 2019-2020 academic year. In the study, one of the qualitative research methods, phenomenology design was used. The findings are presented with percentage and frequency values. According to the findings of the research, undergraduate students produced 180 metaphors for the concept of "vacation". However, 10 metaphors, whose meaningless, were excluded from the study, and the analyses were carried out on 170 metaphors. These metaphors are grouped under 11 different conceptual categories. In the study, it was concluded that the most "rest" metaphor was produced for the concept of "vacation".
\end{abstract}

Keywords: Vacation, Metaphor Analysis, Associate Degree Student, Department of Tourism and Hotel Management.

Received: 24.02 .2021

Accepted: 05.06.2021

\section{Suggested Citation:}

Gül, M. and Gül, K. (2021). Analysis of the Perception of Tourism and Hotel Management Associate Degree Students about the Concept of "Vacation" with the Metaphors, Journal of Turkish Tourism Research, 5(2): 1404-1423.

(C) 2021 Türk Turizm Araştırmaları Dergisi. 


\section{Gíriş}

Turizm, dinlenme, eğlenme, görme, tanıma, sportif karşılaşmalar yapma, temsil veya konser verme, bilgi ve görgüsünü arttırma gibi amaçlarla ya da sadece eğlenmek için duygusal amaçlarla yapılan gezi faaliyetleri demektir (Doğanay, 2001: 12). Bu niteliği ile turizm, günümüzde en önemli boş zaman aktivitelerinden biridir. Birçok insan boş vakitlerini, başka yerleri ziyaret etmek ve gezmek için dolayısıyla tatil yapmak için kullanmaktadır (Kervankıran ve Özdemir, 2013: 121).

Çakıcı ve İyitoğlu (2012: 121), tatil kararının dinamik bir yapıya sahip olduğunu ve turistlerin tatil kararlarını zamana, ülkelere ve kişisel özelliklerine göre farklılık gösterdiğini ileri sürmektedirler. Turistler tatile çıkmadan önce, tatil sürecinde ve tatil sonrasında birçok kararlar alırlar. Bu süreçte gerek turistlerde gerekse turiste hizmet verecek kişilerde oluşan algı, turistlerin sonraki seçim ve davranışlarını etkilemektedir (Woodside ve King, 2001: 3). Turistlerin tatil kararları sonucunda tercih ettikleri destinasyonlar ve coğrafi yerler, somut ve soyut bileşenlerden oluşmaktadır. Turistik destinasyonlar büyüklügüne, fiziksel çekiciliğine, yarattığı psikolojik tatmine, altyapı ve sosyo-kültürel boyutlarına göre de değişiklik gösterebilmektedir (Hosany ve Gilbert, 2010: 514). Bu nedenle tatil kavramına yönelik algının ekonomik, kültürel, sosyolojik, psikolojik, tarihi vb. çok boyutlu olarak incelenmesi daha makul bir yaklaşım olarak değerlendirilmektedir.

Metafor kavramı ilk kez 1980'lerde Lakoff ve Johnson' tarafından yapılan "Metafors We Live By" isimli çalışmada kullanılmıştır (Döş, 2010: 608). Metafor; bir kavram, olgu veya olayın başka bir kavram, olgu veya olaya benzetilerek açıklanmasıdır (Kahyaoğlu ve Kırıktaş, 2016: 60). Metaforlar, insanların hayatı, çevreyi, olayları ve nesneleri nasıl gördükleri; farklı benzetmeler kullanarak açıklamaya çalışmada kullandıkları bir araç olarak düşünülmektedir (Cerit, 2008: 694). Saban (2009: 282) ise metaforların, bir bireyin zihninin belli bir kavrayış biçiminden başka bir kavrayış biçimine doğru yönelmesini sağlayarak o bireyin belli bir olguyu başka bir olgu olarak görmesine olanak tanıdığını belirtmektedir. Yob (2003: 134) ise metaforu, "bir kişinin alışılmışın dışında, anlaşılması zor, soyut ya da teorik bir kavramı anlamada ve açıklamada kullanılan bir araç" olarak ele almaktadır. Lakoff ve Johnson (2005), insanın düşünce sürecinin büyük ölçüde metaforik olduğunu, Kintsch (2000: 258) ise metaforların herhangi bir konu ile aracı kavramlar arasındaki etkileşimli bağlantıyı gösterdiğini ileri sürmektedir.

Metafor analizi temel kavramsallaştırma araştırmalarında kullanılan en etkili yöntemlerden biridir. Nitel bir araştırma aracı olan metafor analizi, araştırmacılara, kavramsal metaforları inceleme imkânı vererek belirli bir konunun düşünce kalıplarını ve anlayışlarını anlama olanağı sağlamaktadır (Köroğlu vd., 2018: 101). Metafor analizi ile ilgili alanyazın incelendiğinde, 1980'lerden bu yana daha çok eğitim bilimleri alanında çalışmalar yapıldığı, buna karşın turizme yönelik metafor analizi çalışmalarının sınırlı sayıda olduğu anlaşılmaktadır. Turizm ve Otel İşletmeciliği bölümünde öğrenim gören önlisans öğrencileri, mezuniyet sonrasında turizm sektöründe aktif olarak çalışacak ara elemanlardır. Bu nedenle turizm olayının gerçekleşmesinde gerekli olan tatil kavramı ile ilgili algıları oldukça büyük önem kazanmaktadır. Bu noktadan hareketle çalışmanın amacı, Turizm ve Otel İşletmeciliği bölümü önlisans öğrencilerinin tatil kavramına ilişkin algılarının belirlenmesidir. Böylece, turizm olgusunun asli unsurlarından biri olan hizmet sunucularının tatil kavramına ilişkin algılarının belirlenmesi ve mevcut durumun tespit edilmesi, ileride geliştirilecek turizm stratejileri açısından önem taşımaktadır. 


\section{KAVRAMSAL ÇERÇEVE}

\section{Tatil Kavramı}

Tatil, deneyimsel bir süreç olup, katılmadan tecrübe edilememektedir. Deneyimsel öğrenme bağlamları olarak kabul edilmekte olan tatillerde bilgi, deneyimin dönüşümü yoluyla yaratılmaktadır. Örneğin; bir çocuğun tatil ile coğrafi bilgisi gelişebilmekte ve aile seyahati deneyimleri ile öğrenmesi sağlanabilmektedir (Bos vd., 2015: 859). Cocco (2010: 41) ise tatile katılan kişilerin genellikle daha meraklı olup, sıra dışı ve otantik deneyimler aradığını iddia etmektedir. Bu kişiler, geleneklerin, yemeklerin, alışkanlıkların ve kültürel mirasın tamamen ulusal ürünler olarak sergilendiği kozmopolit ve uluslararası deneyimler aramaktadır.

Gram (2005: 2) ile Banim vd., (2015: 425) tatili, günlük yaşamdan, rutinden ve ev işlerinden bir kopuş, bir mola olarak tanımlamaktadırlar. Bu nedenle, tatil tipik olarak günlük yaşamda karşılaşılanlardan daha farklı deneyimler yaratmaktadır. Ayrıca tatiller zevk, eğlence ve dinlenme içermekte, yapılandırılmış hayat ve ev yaşamına karşıt olarak daha fazla boş zaman ve daha özgür bir hayatı temsil etmektedir. 1200 Alman ve 800 Danimarkalı yetişkinle yapılan bir araştırmada; aile tatili, "ailenin ortak deneyimler edinmesi" ve "çocukların eğlenmesi ama aynı zamanda dinlenmesi" olarak tanımlanmıştır. Alman ailelerin öncelikli hedefi dinlenmektir. Bu nedenle, Alman aileler çocuklarıyla birbirlerine zaman ayırmayı, rahatlamayı ve özgür olmayı daha önemli bulmaktadır. Amerikan kasabasında yapılan başka bir araştırmanın sonucuna göre ise tatil, aile olarak yeniden bağlanmanın en iyi yoludur (Gram, 2005: 4). Tatil, güzel hava, gevşeme, rahatlama, aktiviteler, birliktelik, çocuk dostu bir atmosfer, eğlence, doğa, yeni deneyimler, iyi yemekler, çekici tesisler, özgürlük ve bağımsızlık gibi dinlenme ve yenilenme etkinliklerinin yanında, yeni insanlar tanımaya, yerel halkla iletişim kurmaya, başka ülkeleri ve kültürleri deneyimlemeye de olanak sağlamaktadır.

Alanyazında çoğu aile için tatilde en önemli hususun "eğlence" olduğu belirtilmektedir. Bazı aileler için birlikte vakit geçirmek önemli iken, bazı aileler için tatilin eğitim yönü daha önemlidir. Bazı ailelerde ebeveynler dinlenme ve rahatlamayı daha çok arzularken, çocuklar ise aktivite aramaktadır (Bos, 2015: 869). Tatil, içerisinde yerellik, kültür, heyecan ve kaçış duygusunu da barındırabilmektedir (Banim vd., 2015: 426). Gardiner vd., (2015: 336) tüketici seyahatlerinde nesil farklılıklarının turizm talebini etkilediğini ileri sürmektedir. Fakat sağlık, yaşa bakılmaksızın tüm tatil kalıplarını etkileyebilmektedir. Özellikle yaşlandıkça sağlık sorunları artanlar için tatiller oldukça önemlidir. Örneğin; kanser tedavisi gören hastalar için kişisel sağlık, sosyal etkinlik, kişisel kimlik ve bağımsızlığın yeniden kazanılması gibi dört katkı alanı belirtilmiştir. Bunun dışında her yaşta ortaya çıkabilen özellikle artrit, diyabet ve kalp hastalığı gibi kronik hastalıkların tedavisinde de tatiller önemli bir seçenek olabilmektedir (Jones ve Blackburn, 2007: 509).

Larsen (2013: 153), mutlu tatilin birlikte bir şeyler yapmaktan geçtiğini ileri sürmektedir. Çinli genç kadınların tatil alışkanlıkları araştıran Chen vd. (2020: 246), Çin'li kadınların en fazla "guimi tatili" olarak bilinen arkadaşlar arasında gerçekleşen tatil türünü tercih ettikleri sonucuna ulaşmışlardır. Kadınlar bu tatiller sayesinde ev işlerinden, eş ve çocuklarından uzaklaşabilmekte, ziyafet ve eğlenceye vakit ayırabilmektedir. Voase (2018) çalışmasında tatili bir kaçış şekli olarak kavramsallaştırmıştır. Bunun yanı sıra boş zaman ve sosyalleşmeyi de simgelemektedir. Gardiner vd., (2015) yürüttügü araştırmada ise Avustralyalıların seyahat güdüleri, yerel ve uluslararası alanda yaşanan değişim açısından incelenmiştir. Buna göre tatil; heyecan, huzur, mutluluk gibi duygular uyandırmakta ve duygusal değer sunmak için bir fırsat olarak ifade edilmektedir. 
Sonuç olarak ülkelerin yurt içi ve yurt dışı tatillerini tanıtabilmesi ve pazarlayabilmesi için tüketicilerin algı ve farklılıklarını anlaması ve konuyla ilgili tutum ve niyetlerini bilmesi gerekmektedir (Gardiner vd., 2015: 337). Yazındaki incelemeler sonucunda tatil ile ilgili deneyimler dört ana alana ayrılabilir. İlk alan, dinlenme ve eğlence ile ilgilidir. Bunlar fiziksel olarak aktif olmaktan çok pasif olarak sınıflandırılmaktadır. İkinci alan, eğitim ile ilgilidir (topluluğa katılmak, kayak dersi almak gibi). Burada daha fazla aktif katılım vardır. Fakat turistler hala olayın çok dışındadır. Üçüncü alan, kaçıştır. Kaçış-uzaklaşma deneyimleri eğitici etkinlikler kadar öğretici olabilmektedir. Örneğin; bir oyunda rol almak, bir orkestrada yer almak veya Büyük Kanyon'dan aşağı inmek aktif katılımı gerektirmektedir. Son alan, daha az aktif olmayı talep etmektedir. Kaçış alanından daha fazla katılım içermekte ve "estetik" olarak adlandırılmaktadır (Gram, 2005: 6).

\section{Metafor Analizine İlişkin Araştırma Alanları}

Alanyazın incelendiğinde, metafor analizi ile ilgili çalışmaların çoğunlukla eğitim bilimleri alanında yoğunlaştığı anlaşılmaktadır. Çalışmalarda öğretmen adaylarının çevre sorunları (Kaya, 2014a), küresel 1sınma (Kaya, 2014b), öğretmen (Saban, 2004), tarih öğretmenliği (Özbaş ve Aktekin, 2013), mikroskop (Ekici, 2016), toplumsal cinsiyet (Aslan, 2015), değer (Aladağ ve Kuzgun, 2015), coğrafya (Geçit ve Gencer, 2011), okul (Doğan, 2014), okul yöneticisi (Zembat vd., 2015), e-kitap ve etkileşimli e-kitap (Özer ve Türel, 2015), üstün yetenekli öğrenciler (Çapan, 2010), öğretmen ve sanatçı (Wells, 2015), üniversite (Uğurlu, 2018), bilim ve bilim insanı (Şenel ve Aslan, 2014) ve akademisyen (Polat vd., 2013) kavramlarına ilişkin algıları metaforlar yoluyla belirlemeye çalışmışlardır.

Alanyazında öğretmen adaylarının dışında metafor analizi kapsamına en fazla alınan gruplardan biri de öğrencilerdir. Bu konudaki çalışmalarda farklı düzeylerde öğrenim gören öğrencilerin oyun (Tok, 2018), internet (Şahin ve Baturay, 2013), sosyal bilgiler dersi (Gömleksiz vd., 2012), fen ve teknoloji dersi ile fen ve teknoloji öğretmeni (Soysal ve Afacan, 2012), facebook (Eren vd., 2014), teknoloji (Karaçam ve Aydın, 2014), doğa (Kahyaoğlu ve Kırıktaş, 2016), çevre (Aydın, 2011; Doğan, 2017), küresel 1sınma (Ateş ve Karatepe, 2013), dans (Ayyıldız, 2016), müzik (Babacan, 2014), ödev (Ekici ve Akdeniz, 2018), merkezi sistem sınavları (Baş ve Kıvılcım, 2019), girişimcilik (Boz ve Duran, 2018) ve kariyer (Korkut ve Keskin, 2016) kavramlarına ilişkin algılarını metaforlar yoluyla belirlemeye çalışmışlardır.

Metafor analizi kapsamında yapılan diğer çalışmalar ise okul yöneticilerinin teknoloji liderliği (Hacıfazlıŏlu vd., 2011), ilk ve ortaokul öğretmenlerinin öğretmen kılavuz kitabına yönelik (Göçer ve Aktürk, 2015), rehber öğretmenlerin rehber öğretmen kavramı (Altun ve Camadan, 2013), kadın akademisyenlerin kadın akademisyen olmaya yönelik (Başarır ve Sarı, 2015), ebeveynlerin çocuk kavramına ilişkin (Pesen, 2015) ve bankalarda örgüt kültürünün belirlenmesine yönelik (Çelik ve Arı, 2017) algılarının araştırılması ile ilgilidir.

Metafor analizi ile ilgili alanyazın incelendiğinde, turizm ile ilişkilendirilen çalışma sayısının sınırlı olduğu dikkat çekmektedir. Dilek vd., (2016) otel çalışanlarının turizm ve barış ilişkisine yönelik metaforik algılarını incelemişler, çalışmanın sonucunda katılımcıların turizm ve barışı bir bütün ve birbirlerinin tamamlayıcısı olarak gördükleri ortaya çıkmıştır. Özder vd., (2012) ortaöğretim öğrencilerinin turizm kavramı ile ilgili algılarını belirlemeye yönelik çalışmalarında, katılımcıların klasik turizm ve çalışma sahası olan Karabük ilinin tarih ve kültürünü ön plana çlkaran metaforlar ürettiklerini tespit etmişlerdir. Bozdoğan ve Sünbül (2016) ise ortaokul öğrencilerinin "müze" kavramına ilişkin metaforlarını araştırmışlar ve öğrencilerin müze kavramı ile ilgili olumlu algılara sahip oldukları ortaya çıkmıştır. Bilgen vd. (2014), meslek lisesi ve meslek yüksekokulu öğrencilerinin termal turizm kavramına yönelik düşüncelerini metafor 
analizi yoluyla incelemiş, araştırmanın sonucunda öğrencilerin termal turizmi; sağlık, yeraltı kaynakları, ekonomik, tatil ve dinlenme olarak algıladıkları ortaya çıkmıştır. Köroğlu vd., (2018) ise kültürel miras kavramına ilişkin metaforları incelemiş ve bu kavrama yönelik en fazla "hazine" metaforunun geliştirildiği ortaya çıkmıştır. Saçılık vd., (2016) de çalışmalarında önlisans öğrencilerinin turizm kavramına yönelik düşüncelerini öğrenmeye çalışmış ve turizme yönelik toplam dokuz kategori tespit etmişlerdir. Bayat (2018: 45) yerel halkın Ağrı Dağı kavramına ilişkin algılarını belirlemeye yönelik yaptığı çalışmada ise Ağrı Dağı ile ilgili algılar turizm, doğa, din, psikoloji, ekonomi ve coğrafi konum olmak üzere altı kategoride toplanmıştır. Bu değerlendirmeler ışı̆̆ında, tatil kavramına ilişkin alanyazında bir çalışmaya gereksinim duyulduğu, çalışmanın bu eksikliği giderebileceği düşünülmektedir.

\section{ARAŞTIRMA YÖNTEMI}

\section{Araştırmanın Amacı}

Araştırmanın amacı, Turizm ve Otel İşletmeciliği bölümü önlisans öğrencilerinin "tatil" kavramına ilişkin algılarını metaforlar aracılığıyla ortaya çıkarmaktır. Bu amaca bağlı olarak çalışmada iki soruya cevap aranmıştır:

1. Önlisans öğrencilerinin "tatil" kavramına ilişkin algıları hangi metaforlar aracıllğıyla ortaya çıkmaktadır?

2. Bu metaforlar hangi kavramsal kategoriler altında toplanabilmektedir?

\section{Araştırmanın Deseni}

$\mathrm{Bu}$ araştırmada, nitel araştırma yöntemlerinden olgubilim (fenomenoloji) deseni kullanılmıştır. Olgubilim deseni, "birkaç kişinin bir olgu veya kavramla ilgili yaşanmış deneyimlerinin ortak anlamını" tanımlamaktadır (Köroğlu vd., 2018: 101). Olgubilim deseni, farkında olunan ancak derinlemesine ve ayrıntılı bir anlayışa sahip olunmayan olgulara odaklanmaktadır. Bize tümüyle yabancı olmayan aynı zamanda da tam anlamını kavrayamadığımız olguları araştırmayı amaçlayan çalışmalar için olgubilim (fenomenoloji) uygun bir araştırma sahasıdır (Yıldırım ve Şimşek, 2011: 72). Olgusal desende önemli olan şey, bireysel tecrübelerdir ve bilincin özünün betimlenmesine dayanmaktadır (Sönmez ve Alacapınar, 2011: 81).

\section{Araştırmanın Örneklemi}

Araştırmanın örneklemini, 2019-2020 eğitim öğretim yılı bahar döneminde Balıkesir Üniversitesi Balıkesir Meslek Yüksekokulu ile Sındırgı Meslek Yüksekokulu Turizm ve Otel İşletmeciliği bölümlerinde öğrenim gören öğrenciler oluşturmaktadır. Turizm ve Otel İşletmeciliği Bölümünde öğrenim gören öğrencilerin örneklem olarak seçilmesinin temel nedeni, öğrencilerin özellikle alan derslerinde tatil kavramına ilişkin oldukça fazla bilgiyle karşılaşmış olmalarıdır. Bundan dolayı, bu öğrencilerin "tatil" kavramına yönelik algılarının diğer bölüm öğrencilerinin algılarına kıyasla daha kapsamlı olduğu düşünülmektedir.

\section{Verilerin Toplanmasi}

Çalışmanın amacına yönelik olarak hazırlanan soru formu öğrencilere sınıf ortamında dağıtılmıştır. Katılım gönüllülük esasına dayalı olup, katılımcı öğrencilere düşünmeleri ve formu doldurmaları için 30 dakika süre verilmiştir. Soru formunda öncelikle öğrencilerin demografik özelliklerinin belirlenmesi amacıyla cinsiyet, yaş ve sınıf soruları yöneltilmiştir. Daha sonra 
araştırmaya katılan önlisans öğrencilerinin "tatil" kavramına ilişkin sahip oldukları metaforları belirlemek amacıyla "Tatil bana ".........." ifade eder. Çünkü, “............" yönündeki ifadeyi tamamlamaları istenmiştir. Öğrenciler sadece bir metaforla sınırlandırılmamış, birden fazla metafor üretmelerine izin verilmiştir. Öğrencilerin formu doldurmaya başlamasından önce metafor kavramı tanımlanmış, çeşitli metafor örnekleri sunularak metafor analizi yöntemi ve amaçları konusunda bilgi verilmiştir. Soru cümlesinde yer alan "... ifade eder" benzetmesi ile metafora anlam yüklenmesi, "çünkü ..." ile başlayan cümle ile de metafora yüklenen anlamın nedeninin tespit edilmesi amaçlanmıştır. Katılımcıların kavrama ilişkin kullandıkları cümleler araştırmanın temel veri kaynağını oluşturmaktadır.

\section{Verilerin Analizi}

Verilerin analizi; kodlama ve ayıklama, kategori geliştirme, geçerlik ve güvenirlik, verilerin analizi ve verilerin yorumlanması olmak üzere beş aşamada gerçekleşmiştir. Bu aşamaların geliştirilmesinde alan yazındaki metafor yöntemi kullanılarak gerçekleştirilen çalışmalar (Köroğlu vd., 2018; Saçlık vd., 2016) esas alınmıştır. Kodlama ve ayıklama aşamasında da aynı çalışmalardan yararlanılmış olup, öncelikle turizm ve otel işletmeciliği bölümü önlisans öğrencilerinin tatil kavramına yönelik geliştirdikleri metaforlar araştırmacılar tarafından incelenmiştir. Veriler değerlendirilirken nedeni belirtilmeyen ve anlamsız olduğu düşünülen toplam 10 metafor elenerek araştırmanın kapsamı dışında bırakılmış ve analizler 170 metafor üzerinden gerçekleştirilmiştir.

Bir sonraki aşamada, öğrencilerin "tatil" kavramina ilişkin üretmiş olduğu metaforlar ortak özellikleri bakımından incelenmiştir. Öğrencilerin metaforun konusu ile kaynağı arasında kurduğu ilişkiden yola çıkılarak, bu metaforların "tatil" kavramını neye dayandırdığına bakılmış ve metaforlar belli bir kodla kodlanmıştır (örneğin; duygusallığa dayanması, sosyalliğe dayanması, eylemlere dayanması, maddiyata dayanması gibi). Daha sonra bu kodlar, "tatil" kavramının özelliklerine göre ifade edilerek, 11 farklı kavramsal kategori oluşturulmuştur. Öğrencilerin "tatil" kavramını deniz-kum-güneş, dinlenme, eğlence gibi klasik bir bakış açısıyla tanımladığı kategori "Klasik Alg̨ Olarak Tatil" olarak adlandırılmıştır. Huzur, mutluluk, özgürlük gibi duygularını katarak ifade ettiği kategori "Psikolojik Algı Olarak Tatil" ve para, altın, masraf gibi maddiyata dayanan değerlerle nitelendirdiği kategori "Finansal Algı Olarak Tatil" olarak nitelendirilmiştir. Aile, arkadaş, dostluk gibi insan ilişkilerine dayandırdığı kategori "Sosyolojik Algı Olarak Tatil" ve Ayvalık, Brezilya, Kapadokya gibi gidilecek yer olarak açıkladığı kategori "Destinasyon (Yer) Algısı Olarak Tatil" olarak kavramsallaştırılmıştır. Çalışmak, yorgunluk, uyku gibi bir eylemle adlandırdığı kategori "Eylem Algısı Olarak Tatil" ve yeni insanları tanımak, keşfetmek, bilgi edinme gibi yeniliklere ve gelişime açı bir unsur olarak ifade ettiği kategori "Gelişim Aracı Algısı Olarak Tatil" olarak adlandırılmıştır. Kum saati, cüzdan, paraşüt gibi varlıklarla nitelendirdiği kategori "Canlı ve Somut Varlık Algısı Olarak Tatil" ve cennet, ödül, hatıra gibi kavramlarla betimlediği kategori "Cansız ve Soyut Varlık Algısı Olarak Tatil" olarak adlandırılırmıştır. Son olarak, tarih, kültür, gelenek-görenek gibi öğelere dayandırdı̆̆ı kategori "Tarihi ve Kültürel Algı Olarak Tatil" ve turizm, tatil köyü, otel gibi turistik unsurlarla açıkladığı kategori ise "Turistik Algı Olarak Tatil" olarak isimlendirilmiştir.

Daha sonra kategorilerin yüzdelik dağılımları belirlenmiştir. Psikolojik Algı Olarak Tatil kategorisi 34 metafor ile en fazla metafor bulunan kategoridir. Cansız ve Soyut Varlık Algisı Olarak Tatil kategorisinde 30, Klasik Alg1 Olarak Tatil kategorisinde 25, Gelişim Aracı Olarak Tatil ile Canlı ve Somut Varlık Algısı Olarak Tatil kategorisinde 19, Sosyolojik Alg1 Olarak Tatil ile Eylem Algısı Olarak Tatil kategorisinde 9, Finansal Algı Olarak Tatil ile Destinasyon (Yer) 
Alg1sı Olarak Tatil kategorisinde 7, Turistik Alg1 Olarak Tatil kategorisinde 6 ve Tarihi ve Kültürel Alg 1 Olarak Tatil kategorisinde 5 metafor bulunmaktadır.

Çalışmanın geçerliliğinin sağlanması amacıyla verilerin toplanması ve analiz edilmesi aşamaları ayrıntılı bir şekilde sunulmuş ve metaforların dayandırıldığı kategorilerin nasıl oluşturulduğu belirtilmiştir. Nitel bir araştırmanın geçerliğinin önemli ölçütlerinden biri; toplanan verilerin ayrıntılı olarak rapor edilmesi ve araştırmacının sonuçlara nasıl ulaştığını açıklamasıdır (Yıldırım ve Şimşek, 2011: 257). Çalışmanın güvenirliği, kodlanacak veriler, kodlamayı yapacak kişiler tarafından birlikte kodlanmış ve her birinin yaptığı kodlamalar birbirleri tarafından gözden geçirilerek sağlanmıştır. Araştırma birden fazla araştırmacı dahil edilerek yürütülmüştür. Çünkü araştırmacılar arasında araştırmanın çeşitli süreçlerinde oluşacak uzlaşma noktaları, araştırmanın başkaları tarafından kabul edilme oranını da arttırmaktadır. Bu yöntemde Miles ve Huberman'ın (1994) formülüne göre güvenirlik, kodlanan ve üzerinde mutabık kalınan kod sayısının, üzerinde mutabık kalınan ve kalınmayan kod sayısına bölünmesiyle elde edilmektedir (Güvenirlik=Kodlanan ve üzerinde mutabık kalınan kod sayısı/Mutabık kalınan kod sayısı+Mutabık kalınmayan kod sayısı) (akt. Yıldırım ve Şimşek, 2008: 395). Buna göre bu çalışmanın güvenirliği $(100=170 /(170+10) \% 94$ olarak hesaplanmıştır. Miles ve Huberman'a göre (1994) uzman ve araştırmacı değerlendirmeleri arasındaki uyumun \%90'a yaklaşması ya da \% 90'1 geçmesi durumunda arzu edilen düzeyde bir güvenilirlik sağlanmış olmaktadır (Saban, 2008: 467). Verilerin analizi aşamasında 170 metafor ve 11 kategoriyi temsil eden katılımcı sayıları (f) ve yüzdelik oranları (\%) hesaplanmıştır. Son aşamada ise veriler yorumlanmıştır.

\section{BULGULAR ve TARTIŞMA}

$\mathrm{Bu}$ bölümde araştırmaya katılan önlisans öğrencilerinin tatil kavramına ilişkin ürettikleri metaforlar ve bu metaforların oluşturduğu kategoriler sunulmaktadır.

\section{Önlisans Öğrencilerine İlişkin Demografik Veriler}

Araştırmaya katılan öğrencilerin \%77,8'i Balıkesir Meslek Yüksekokulu ve \%22,1'i Sındırg1 Meslek Yüksekokulu öğrencilerinden oluşmaktadır. Öğrencilerin \%65'i erkek ve \%35'i de kız öğrencidir. Öğrencilerin \%60'ı 18-20 yaş, \%34,2'si 21-23 yaş ve \%5,7'si 24 yaş ve üzeri yaş aralığında bulunmaktadır. Öğrencilerin sınıf dağılımına bakıldığında \%54,2'sinin 1 . sınıf ve $\% 45,7$ 'sinin 2. sinıf olduğu görülmektedir.

\section{Önlisans Öğrencilerinin Tatil Kavramına İlişkin Metaforları}

Araştırmaya katılan Turizm ve Otel İşletmeciliği önlisans öğrencileri tatil kavramına ilişkin 170 metafor üretmişlerdir. Bu metaforlar, frekansları ve yüzdeleri ile birlikte Tablo 1'de gösterilmektedir.

Tablo 1'den de görülebileceği gibi, turizm ve otel işletmeciliği bölümü önlisans öğrencilerinin "tatil" kavramına ilişkin 170 adet geçerli metafor ürettiği görülmektedir. Bu metaforlar içinde yer alan dinlenme metaforu 42 kişi $(\% 7,52)$ tarafından en fazla üretilen metafor olmuştur. Bunu 40 'ar kişi $(\% 7,16)$ tarafından üretilen eğlence ve huzur metaforları takip etmektedir. Bununla birlikte mutluluk ( $\mathrm{f}=24)$, rahatlık ( $\mathrm{f}=24)$, deniz-kum-güneş $(\mathrm{f}=21)$, özgürlük ( $\mathrm{f}=19)$, gezmek ( $\mathrm{f}=14)$, deniz $(\mathrm{f}=13)$, yeni insanları tanımak $(\mathrm{f}=11)$, aile $(\mathrm{f}=10)$, para $(\mathrm{f}=10)$ ve boş zaman değerlendirme $(\mathrm{f}=10)$ gibi metaforların da en sık üretilen metaforlar arasında olduğu belirlenmiştir. 
Tablo 1. Önlisans Öğrencilerinin "Tatil" Olgusuna İlişkin Ürettikleri Metaforlar

\begin{tabular}{|c|c|c|c|c|c|c|c|}
\hline Sir & Metafor & Freka & $(\%)$ & Sira & Metafor & Freka & $(\%)$ \\
\hline 1. & Dinlenme & 42 & 7.52 & 86. & Gençlik & 1 & 0.17 \\
\hline 2. & Eğlence & 40 & 7.16 & 87. & Ağrı kesici & 1 & 0.17 \\
\hline 3. & Huzur & 40 & 7.16 & 88. & Beyaz bir sayfa & 1 & 0.17 \\
\hline 4. & Mutluluk & 24 & 4.30 & 89. & Karanlık bir oda & 1 & 0.17 \\
\hline 5. & Rahatlık & 24 & 4.30 & 90. & Güneşli günler & 1 & 0.17 \\
\hline 6. & Deniz-kum-güneş & 21 & 3.76 & 91. & Mevsimler & 1 & 0.17 \\
\hline 7. & Özgürlük & 19 & 3.40 & 92. & Sicaklık & 1 & 0.17 \\
\hline 8. & Gezmek & 14 & 2.50 & 93. & Sahil & 1 & 0.17 \\
\hline 9. & Deniz & 13 & 2.32 & 94. & Kumsal & 1 & 0.17 \\
\hline 10. & Yeni insanları tanımak & 11 & 1.97 & 95. & Adrenalin & 1 & 0.17 \\
\hline 11. & Aile & 10 & 1.79 & 96. & Altın & 1 & 0.17 \\
\hline 12. & Para & 10 & 1.79 & 97. & Fakirlik & 1 & 0.17 \\
\hline 13. & Boş zaman değerlendirme & 10 & 1.79 & 98. & Tutumluluk & 1 & 0.17 \\
\hline 14. & Doğa güzellikleri & 7 & 1.25 & 99. & Anne & 1 & 0.17 \\
\hline 15. & Yolculuk & 7 & 1.25 & 100. & Annem & 1 & 0.17 \\
\hline 16. & Çalışmak & 7 & 1.25 & 101. & Sosyalleşme & 1 & 0.17 \\
\hline 17. & Uyku & 7 & 1.25 & 102. & Evlatlarım & 1 & 0.17 \\
\hline 18. & Arkadaş & 6 & 1.07 & 103. & Kozmopolizm & 1 & 0.17 \\
\hline 19. & Uzaklaşma & 6 & 1.07 & 104. & Arizona & 1 & 0.17 \\
\hline 20. & Güneş & 5 & 0.89 & 105. & Ayvalık & 1 & 0.17 \\
\hline 21. & Gezip görmek & 5 & 0.89 & 106. & Brezilya & 1 & 0.17 \\
\hline 22. & Yüzme & 5 & 0.89 & 107. & Kapadokya & 1 & 0.17 \\
\hline 23. & Kültür & 5 & 0.89 & 108. & Kutuplar & 1 & 0.17 \\
\hline 24. & Seyahat & 4 & 0.71 & 109. & Çocuk park 1 & 1 & 0.17 \\
\hline 25. & Alkol & 4 & 0.71 & 110. & Çalışmamak & 1 & 0.17 \\
\hline 26. & Keşfetmek & 4 & 0.71 & 111. & Deney & 1 & 0.17 \\
\hline 27. & Dinginlik & 4 & 0.71 & 112. & Emek & 1 & 0.17 \\
\hline 28. & Heyecan & 3 & 0.53 & 113. & Fotoğraf çekmek & 1 & 0.17 \\
\hline 29. & Sikıntı & 3 & 0.53 & 114. & Sevişme & 1 & 0.17 \\
\hline 30. & Kafa dinlemek & 3 & 0.53 & 115. & Yeni dilleri tanımak & 1 & 0.17 \\
\hline 31. & Boşluk & 3 & 0.53 & 116. & Başlangıçlar & 1 & 0.17 \\
\hline 32. & Pazar günü & 3 & 0.53 & 117. & Ufkumun genişlemesi & 1 & 0.17 \\
\hline 33. & Ekonomi & 3 & 0.53 & 118. & Tecrübe & 1 & 0.17 \\
\hline 34. & Dostluk & 3 & 0.53 & 119. & Serüven & 1 & 0.17 \\
\hline 35. & Yorgunluk & 3 & 0.53 & 120. & Okul & 1 & 0.17 \\
\hline 36. & Spor & 3 & 0.53 & 121. & Öğretmen & 1 & 0.17 \\
\hline 37. & Yenilikler & 3 & 0.53 & 122. & Gelişme & 1 & 0.17 \\
\hline 38. & Yeni mekânlar & 3 & 0.53 & 123. & Farklı aktiviteler & 1 & 0.17 \\
\hline 39. & Öğrenme & 3 & 0.53 & 124. & Farklı bir dünya & 1 & 0.17 \\
\hline 40. & Farklı şehirler & 3 & 0.53 & 125. & Araştırmacilık & 1 & 0.17 \\
\hline 41. & Kum saati & 3 & 0.53 & 126. & Yatak & 1 & 0.17 \\
\hline
\end{tabular}




\begin{tabular}{|c|c|c|c|c|c|c|c|}
\hline 42. & Zaman & 3 & 0.53 & 127. & Saat & 1 & 0.17 \\
\hline 43. & Sakinlik & 3 & 0.53 & 128. & Silgi & 1 & 0.17 \\
\hline 44. & Ödül & 3 & 0.53 & 129. & Yemekten sonra yenen tatlı & 1 & 0.17 \\
\hline 45. & Hayal etmek & 3 & 0.53 & 130. & Unutma beni çiçeği & 1 & 0.17 \\
\hline 46. & Tarih & 3 & 0.53 & 131. & Paraşüt & 1 & 0.17 \\
\hline 47. & Aşk & 2 & 0.35 & 132. & Milkshake & 1 & 0.17 \\
\hline 48. & Sevgi & 2 & 0.35 & 133. & Kalem & 1 & 0.17 \\
\hline 49. & Kalabalık & 2 & 0.35 & 134. & Kedi & 1 & 0.17 \\
\hline 50. & Ölüm & 2 & 0.35 & 135. & Eskimiş fotoğraf & 1 & 0.17 \\
\hline 51. & Sağlık & 2 & 0.35 & 136. & Cüzdan & 1 & 0.17 \\
\hline 52. & Doğa & 2 & 0.35 & 137. & Ăgaç & 1 & 0.17 \\
\hline 53. & Bronzlaşma & 2 & 0.35 & 138. & Anka kuşu & 1 & 0.17 \\
\hline 54. & Hafta sonu & 2 & 0.35 & 139. & Bitki & 1 & 0.17 \\
\hline 55. & Yaz ayı & 2 & 0.35 & 140. & Hamsi & 1 & 0.17 \\
\hline 56. & Serin yaz akşamları & 2 & 0.35 & 141. & Hayvanlar & 1 & 0.17 \\
\hline 57. & Borç & 2 & 0.35 & 142. & Kelebek & 1 & 0.17 \\
\hline 58. & Masraf & 2 & 0.35 & 143. & Yildizlar & 1 & 0.17 \\
\hline 59. & İlişki & 2 & 0.35 & 144. & Kırmızı & 1 & 0.17 \\
\hline 60. & Ülke & 2 & 0.35 & 145. & Renkler & 1 & 0.17 \\
\hline 61. & Değişiklik & 2 & 0.35 & 146. & Soyutluk & 1 & 0.17 \\
\hline 62. & Bilgi edinme & 2 & 0.35 & 147. & Sonsuzluk & 1 & 0.17 \\
\hline 63. & Gece kulübü & 2 & 0.35 & 148. & Sadelik & 1 & 0.17 \\
\hline 64. & Cennet & 2 & 0.35 & 149. & Sabirsızlık & 1 & 0.17 \\
\hline 65. & Hatıra & 2 & 0.35 & 150. & Kadayıf & 1 & 0.17 \\
\hline 66. & Kar yağışı & 2 & 0.35 & 151. & Sessizlik & 1 & 0.17 \\
\hline 67. & Gelenek görenek & 2 & 0.35 & 152. & Savaş galibiyeti & 1 & 0.17 \\
\hline 68. & Turizm & 2 & 0.35 & 153. & Öykü & 1 & 0.17 \\
\hline 69. & Otel & 2 & 0.35 & 154. & Nehir & 1 & 0.17 \\
\hline 70. & Duygusallık & 1 & 0.17 & 155. & Matruşka & 1 & 0.17 \\
\hline 71. & Gökyüzü & 1 & 0.17 & 156. & Gizem & 1 & 0.17 \\
\hline 72. & Hüzün & 1 & 0.17 & 157. & Hediye & 1 & 0.17 \\
\hline 73. & İhtiyaç & 1 & 0.17 & 158. & Dinamiklik & 1 & 0.17 \\
\hline 74. & Psikolojik destek & 1 & 0.17 & 159. & Temizlik & 1 & 0.17 \\
\hline 75. & Psikolog & 1 & 0.17 & 160. & Annesini kızdıran çocuğun ağlaması & 1 & 0.17 \\
\hline 76. & Psikiyatri & 1 & 0.17 & 161. & Akdeniz akşamları & 1 & 0.17 \\
\hline 77. & Stres & 1 & 0.17 & 162. & Hava & 1 & 0.17 \\
\hline 78. & Stres atma & 1 & 0.17 & 163. & Hayatı anlamak & 1 & 0.17 \\
\hline 79. & Sevinç & 1 & 0.17 & 164. & $\mathrm{Su}$ & 1 & 0.17 \\
\hline 80. & Zevk & 1 & 0.17 & 165. & Sanat eserleri & 1 & 0.17 \\
\hline 81. & Üzülme & 1 & 0.17 & 166. & Örf adet & 1 & 0.17 \\
\hline 82. & Tutku & 1 & 0.17 & 167. & Tatil köyü & 1 & 0.17 \\
\hline 83. & Şehvet & 1 & 0.17 & 168. & Otobüs & 1 & 0.17 \\
\hline 84. & Müzik & 1 & 0.17 & 169. & Mola & 1 & 0.17 \\
\hline
\end{tabular}




\begin{tabular}{|c|l|c|c|l|l|c|c|}
\hline $\mathbf{8 5 .}$ & Keyif & 1 & 0.17 & $\mathbf{1 7 0 .}$ & Festival & 1 & 0.17 \\
\hline & & & \multicolumn{3}{|c|}{ Toplam } & $\mathbf{5 5 8}$ & $\mathbf{1 0 0}$ \\
\hline
\end{tabular}

\section{Önlisans Öğrencilerinin "Tatil" Kavramına İlişkin Ürettikleri Metaforların Oluşturdukları Kategoriler}

Turizm ve Otel İşletmeciliği bölümü önlisans öğrencilerinin "Tatil" kavramına ilişkin ürettikleri metaforlar, 11 kategori altında toplanmış ve bu kategoriler Tablo 2'de gösterilmiştir.

Tablo 2. Önlisans Öğrencilerinin Tatil Kavramına İlişkin Ürettikleri Metaforlar

\begin{tabular}{|c|c|c|c|c|}
\hline Kategoriler & Metaforlar & Adet & Fr. & $(\%)$ \\
\hline $\begin{array}{l}\text { 1. Psikolojik Alg1 } \\
\text { Olarak Tatil }\end{array}$ & $\begin{array}{l}\text { Aşk (2), Duygusallık (1), Gökyüzü (1), Heyecan (3), Huzur (40), Hüzün } \\
\text { (1), İhtiyaç (1), Mutluluk (24), Özgürlük (19), Psikolojik Destek (1), } \\
\text { Psikolog (1), Psikiyatri (1), Rahatlık (24), Sıkıntı (3), Stres (1), Stres } \\
\text { Atma (1), Sevinç (1), Zevk (1), Üzülme (1), Tutku (1), Sevgi (2), Şehvet } \\
\text { (1), Müzik (1), Keyif (1), Gençlik (1), Kalabalık (2), Kafa Dinlemek (3), } \\
\text { Alkol (4), Ağrı Kesici (1), Ölüm (2), Boşluk (3), Beyaz Bir Sayfa (1), } \\
\text { Karanlık Bir Oda (1) ve Sağlık (2) }\end{array}$ & 34 & 153 & 27.42 \\
\hline $\begin{array}{l}\text { 2. Cansız ve Soyut } \\
\text { Varlık Algısı Olarak } \\
\text { Tatil }\end{array}$ & $\begin{array}{l}\text { Yıldızlar (1), Cennet (2), Kırmızı (1), Renkler (1), Zaman (3), Soyutluk } \\
\text { (1), Sonsuzluk (1), Sadelik (1), Sabırsızlık (1), Kadayıf (1), Sakinlik (3), } \\
\text { Sessizlik (1), Savaş Galibiyeti (1), Hatıra (2), Öykü (1), Ödül (3), Nehir } \\
\text { (1), Matruşka (1), Gizem (1), Hediye (1), Dinamiklik (1), Dinginlik (4), } \\
\text { Temizlik (1), Annesini Kızdıran Çocuğun Ağlaması (1), Akdeniz } \\
\text { Akşamları (1), Hava (1), Hayal Etmek (3), Hayatı Anlamak (1), Kar } \\
\text { Yağı̧̧ı (2), Su (1) }\end{array}$ & 30 & 44 & 7.89 \\
\hline $\begin{array}{l}\text { 3. Klasik Algi Olarak } \\
\text { Tatil }\end{array}$ & $\begin{array}{l}\text { Deniz/kum/güneş (21), Dinlenme (42), Deniz (13), Uzaklaşma (6), } \\
\text { Doğa (2), Eğlence (40), Doğa Güzellikleri (7), Bronzlaşma (2), Güneş } \\
\text { (5), Gezmek (14), Güneşli Günler (1), Pazar Günü (3), Gezip Görmek } \\
\text { (5), Hafta Sonu (2), Mevsimler (1), Sıcaklık (1), Sahil (1), Seyahat (4), } \\
\text { Yüzme (5), Yolculuk (7), Yaz Ayı (2), Serin Yaz Akşamları (2), Kumsal } \\
\text { (1), Adrenalin (1) ve Boş Zaman Değerlendirme (10) }\end{array}$ & 25 & 198 & 35.48 \\
\hline $\begin{array}{l}\text { 4. Canlı ve Somut } \\
\text { Varlık Algısı Olarak } \\
\text { Tatil }\end{array}$ & $\begin{array}{l}\text { Yatak (1), Saat (1), Silgi (1), Yemekten Sonra Yenen Tatlı (1), Unutma } \\
\text { Beni Çiçeği (1), Paraşüt (1), Milkshake (1), Kum Saati (3), Kalem (1), } \\
\text { Kedi (1), Gece Klübü (2), Eskimiş Fotoğraf (1), Cüzdan (1), Ağaç (1), } \\
\text { Anka Kuşu (1), Bitki (1), Hamsi (1), Hayvanlar (1), Kelebek (1) }\end{array}$ & 19 & 22 & 3.94 \\
\hline $\begin{array}{l}\text { 5. Gelişim Aracı Algısı } \\
\text { Olarak Tatil }\end{array}$ & $\begin{array}{l}\text { Yeni Dilleri Tanımak (1), Yeni İnsanları Tanımak (11), Başlangıçlar (1), } \\
\text { Yenilikler (3), Yeni Mekanlar (3), Ufkumun Genişlemesi (1), Tecrübe } \\
\text { (1), Serüven (1), Öğrenme (3), Okul (1), Öğretmen (1), Keşfetmek (4), } \\
\text { Gelişme (1), Farklı Şehirler (3), Farklı Aktiviteler (1), Farklı Bir Dünya } \\
\text { (1), Değişiklik (2), Araştırmacılık (1), Bilgi Edinme (2) }\end{array}$ & 19 & 42 & 7.53 \\
\hline $\begin{array}{l}\text { 6.Sosyolojik Alg1 } \\
\text { Olarak Tatil }\end{array}$ & $\begin{array}{l}\text { Aile (10), Arkadaş (6), Anne (1), Annem (1), Dostluk (3), İlişki (2), } \\
\text { Sosyalleşme (1), Evlatlarım (1), Kozmopolizm (1) }\end{array}$ & 9 & 26 & 4.66 \\
\hline $\begin{array}{l}\text { 7. Eylem Algisı Olarak } \\
\text { Tatil }\end{array}$ & $\begin{array}{l}\text { Çalışmak (7), Yorgunluk (3), Çalışmamak (1), Deney (1), Emek (1), } \\
\text { Fotoğraf Çekmek (1), Spor (3), Sevişme (1), Uyku (7) }\end{array}$ & 9 & 25 & 4.48 \\
\hline $\begin{array}{l}\text { 8. Finansal Algi Olarak } \\
\text { Tatil }\end{array}$ & $\begin{array}{l}\text { Altın (1), Borç (2), Ekonomi (3), Fakirlik (1), Masraf (2), Para (10), } \\
\text { Tutumluluk (1) }\end{array}$ & 7 & 20 & 3.58 \\
\hline $\begin{array}{l}\text { 9. Destinasyon (Yer) } \\
\text { Alg1si Olarak Tatil }\end{array}$ & $\begin{array}{l}\text { Arizona (1), Ayvalık (1), Brezilya (1), Kapadokya (1), Ülke (2), } \\
\text { Kutuplar (1), Çocuk Parkı (1) }\end{array}$ & 7 & 8 & 1.43 \\
\hline $\begin{array}{l}\text { 10. Turistik Alg1 Olarak } \\
\text { Tatil }\end{array}$ & Turizm (2), Tatil Köyü (1), Otel (2), Otobüs (1), Mola (1), Festival (1) & 6 & 8 & 1.43 \\
\hline \multirow[t]{2}{*}{$\begin{array}{l}\text { 11. Tarihi ve Kültürel } \\
\text { Alg1 Olarak Tatil }\end{array}$} & $\begin{array}{l}\text { Tarih (3), Sanat Eserleri (1), Örf Adet (1), Kültür (5), Gelenek Görenek } \\
\text { (2) }\end{array}$ & 5 & 12 & 2.15 \\
\hline & TOPLAM & 170 & 558 & 100 \\
\hline
\end{tabular}




\section{Psikolojik Algı Olarak Tatil Kategorisi}

Öğrencilerin "tatil" kavramın duygularını katarak ve psikolojik durumları ile de ilişkilendirerek ifade ettikleri bu kategoride 34 adet metafor üretilmiştir. Toplamda üretilen metaforlar içerisinde $\%$ 27,42'lik bir orana sahip olan bu kategoride en fazla üretilen metaforlar; huzur ( $\mathrm{f}=40)$, mutluluk $(\mathrm{f}=24)$, rahatlık ( $\mathrm{f}=24)$ ve özgürlük ( $\mathrm{f}=19)$ metaforlarıdır. Bu kategoriyle ilgili öğrencilerin metafor geliştirme nedenlerine yönelik görüşlerinden bazıları aşağı da sunulmuştur:

"Tatil bana heyecan ifade eder. Çünkü yeni yerler keşfederim, küçük bir çocuğun ilk defa bayramda ayakkabı alması ve içi içine sığmamasına benzer."

"Tatil bana mutluluk ifade eder. Çünkü eğlenirsin, gevşersin, sevdiklerinle vakit geçirerek mutlu olursun, memleketimden uzak bir yer olması üzerimdeki stresi atar, duygularımı rahat bırakıyorum ve bu beni mutlu eder."

"Tatil bana huzuru ifade eder. Çünkü kendim için ayırdığım her vakit beni motive eder ve huzur verir, herkesten uzak olup kafa dinlerim, doğayı ve doğal güzellikleri görüp keşfetmek içimde huzur sağlar."

"Tatil bana özgürlü̆g̈̈ ifade eder. Çünkü o gün için hayattaki sorumluluklardan vazgeçeriz, bütün gün bana ait oluyor ve kendime zaman ayırabiliyorum, herkesin isteklerine göre şekillenir, insanlarm hapis olduğu monoton hayatlarından kısa süreliğine bile olsa kaçması anlamına gelir, denizin maviliğinde kaybolmak isterim."

"Tatil bana gökyüzünü ifade eder. Çünkü tatil de gökyüzü kadar sonsuzdur."

"Tatil bana alkolü ifade eder. Çünkü alkol aldığımızda da tatile gittiğimizde de zamanın nasıl geçtiğini anlamayız."

"Tatil bana sağhlğ̆ ifade eder. Çünkü insanlar sağlık için tatile gider, kendilerini iyi hissetmek için psikolojik olarak hastalıklarını yenerler, tuzlu suyun ve güneş ışılarının cilde olan faydasından yararlanırlar."

"Tatil bana rahatlı̆̆ ifade eder. Çünkü bedenen ve ruhen dinlenmeye yarar, hayatın monotonluğundan uzaklaşmayı ve şehrin gürültüsünden kurtulmayı să̆lar, yoğun iş temposu ve beyin yorgunluğundan bir nebze de olsun kaçmaya yardımcı olur."

"Tatil bana beyaz bir sayfayı ifade eder. Çünkü o beyaz sayfayı eğlenerek, gezerek dolu dolu yaşayarak doldurabiliriz."

"Tatil bana psikoloğu ifade eder. Çünkü güzel bir tatil sonunda bir psikologla konuşmuş gibi rahatlarm."

\section{Cansız ve Soyut Varlık Algısı Olarak Tatil Kategorisi}

Öğrenciler bu kategoride tatil kavramını cansız ve soyut varlıklar ile betimlemişlerdir. 30 adet metafor üretilen kategorinin toplam metaforlar içerisindeki oranı \% 7,89'dur. Bu kategoride en fazla üretilen metaforlar; dinginlik ( $\mathrm{f}=4$ ), ödül, sakinlik ve hayal etmek ( $\mathrm{f}=3$ ), kar yağışı $(\mathrm{f}=2$ ) metaforlarıdır. Öğrencilerin bu kategoriye ilişkin metafor geliştirmeye yönelik görüşlerinden bazıları aşağıda sunulmaktadır:

"Tatil bana dinginliği ifade eder. Çünkü insan beyni çok yorulur ve böyle zamanlarda rahatlar. Insan ruhen kendi kendini yeniler."

"Tatil bana ödülü ifade eder. Çünkü onun için mücadele ederiz, yaşadığımız yoğun hayat temposunun karşılığı gibidir."

"Tatil bana nehri ifade eder. Çünkü nehrin suyu gibi hızlı ve akıcıdır." 
"Tatil bana kadayıfı ifade eder. Çünkü hiçbir zaman çatala tam uymaz."

"Tatil bana öyküyü ifade eder. Çünkü gezip görülecek yerler anlatılan öykülerle daha da güzelleşir."

"Tatil bana matruşkayı ifade eder. Çünkü dış görünüşü sorunsuz gözükse de içinden pek çok iyi veya kötü şey çıkabilir."

"Tatil bana havayı ifade eder. Çünkü daraldığımız bir dönemden kaçarak nefes almaya çalışırız."

\section{Canlı ve Somut Varlık Algısı Olarak Tatil Kategorisi}

Öğrencilerin tatil kavramın canlı ve somut varlıklarla nitelendirdiği bu kategoride toplam 19 adet metafor üretilmiştir ve toplam içerisinde \% 3,94'lük orana sahiptir. Bu kategoride üretilen metaforlardan bazıları; kum saati ( $\mathrm{f}=3$ ) ve bitki, hamsi, kelebek, silgi, kedi ( $\mathrm{f}=1)$ metaforlarıdır. Öğrencilerin bu metaforları geliştirmeye yönelik nedenleri ise aşağıda özetlenmektedir:

"Tatil bana kum saatini ifade eder. Çünkü çok güzel vakit geçirdiğimiz için çabuk biter."

"Tatil bana bitkiyi ifade eder. Çünkü güzel kokan bir bitki nasıl huzur veriyorsa tatil de öyle huzur verir."

"Tatil bana kelebeği ifade eder. Çünkü onun gibi kısa bir ömrü vardır."

"Tatil bana hamsiyi ifade eder. Çünkü her ikisi de boyu kadar kısa tadı kadar güzeldir."

"Tatil bana silgiyi ifade eder. Çünkü kötü anları unutup kafamızı dinleyebiliriz."

"Tatil bana kedileri ifade eder. Çünkü kediler dış görünüm olarak yumuşak ve sevimli görünümlerinin arkasında nankör ve elde edilemez bir yapıya sahiptir. Aynı şekilde tatil de sevimli görünür ama ele geçirmek zordur."

\section{Gelişim Aracı Algısı Olarak Tatil Kategorisi}

Yeniliklere ve gelişime açık bir unsur olarak ifade edilen bu kategoride üretilen metafor sayısı 19 'dur ve toplam içerisinde $\% 7,53$ 'lük dilimi oluşturmaktadır. Bu kategoride en fazla üretilen metaforlar; yeni insanları tanımak ( $\mathrm{f}=11)$, keşfetmek $(\mathrm{f}=4)$, öğrenme $(\mathrm{f}=3)$ ve farklı şehirler $(\mathrm{f}=3)$ metaforlarıdır. $\mathrm{Bu}$ kategoriyle ilgili öğrencilerin metafor geliştirme nedenlerine yönelik görüşlerinden bazıları aşağıda sunulmaktadır:

"Tatil bana yeni insanlar tanımayı ifade eder. Çünkü tatillerde yeni mekanlarda değişik insanlarla tanışırım, her yeni yer başka bir hayat, bir bilmecedir. Çözmek bize kalmıştır."

"Tatil bana keşfetmeyi ifade eder. Çünkü tanınmamış coğrafyaları, kültürleri tanımaktır."

"Tatil bana öğrenmeyi ifade eder. Çünkü gittiğimiz yerlerin kültürünü, tarihini, yaşam tarzlarını öğreniriz."

"Tatil bana farklı bir dünya ifade eder. Çünkü sıradan hayatımızdan uzaklaşıp yeni yerler ve yeni insanlar keşfetmemizi sağlar."

"Tatil bana serüveni ifade eder. Çünkü iyi gezilerle, güzel yerlerle, birçok insanla, uzun yolculuklarla dolu bir serüvendir." 


\section{Sosyolojik Algı Olarak Tatil Kategorisi}

$\mathrm{Bu}$ kategori, öğrencilerin "tatil" kavramını insan ilişkileri ile anlamlandıran yorumlarına dayanmaktadır ve bu kategoride toplam 9 adet metafor üretilmiştir. Bu dilim, toplamda üretilen metaforlar içerisinde $\% 4,66$ 'lık oranı oluşturmaktadır. Bu kategoride en fazla üretilen metaforlar; aile $(\mathrm{f}=10)$, arkadaş $(\mathrm{f}=6)$, dostluk $(\mathrm{f}=3)$ ve ilişki $(\mathrm{f}=2)$ metaforlarıdır. Aşağıdaki bazı öğrenci görüşleri bu kategoriye ilişkin metafor geliştirme nedenlerini özetlemektedir:

"Tatil bana bir anneyi ifade eder. Çünkü yılın 365 günü çocuklarıyla uğraşır."

"Tatil bana aileyi ifade eder. Çünkü ailelerin bir arada gittikleri, güzel vakit geçirdikleri andır, aile ile geçirilen tatil aile bağlarının kuvvetlenmesini sağlar, motivasyonu yükseltir ve o aileyi başarıya götürür."

"Tatil bana kozmopolizmi ifade eder. Çünkü kültürlerin birleşimidir."

\section{Eylem Algısı Olarak Tatil Kategorisi}

Bu kategoride tatil kavramı öğrenciler tarafından bir eylemle ilişkilendirilmiştir ve toplam 9 adet metafor üretilmiştir. Toplamda üretilen metaforlar içerisinde \%4,48'lik dilimi oluşturan kategoride en fazla çalışmak $(\mathrm{f}=7)$, uyku $(\mathrm{f}=7)$, yorgunluk $(\mathrm{f}=3)$ ve spor $(\mathrm{f}=3)$ metaforları üretilmiştir. Öğrencilerin metafor geliştirme nedenlerine yönelik görüşlerinden bazıları aşağıda sunulmaktadır:

"Tatil bana emeği ifade eder. Çünkü bir emeğin karşılığıdır."

"Tatil bana uykuyu ifade eder. Çünkü ne kadar uyursak uyuyalım tadına doyamayız. Ne kadar çok tatile gidersek gidelim onun da tadına doyamayız, yeterli gelmez."

"Tatil bana yorgunluk iade eder. Çünkü tatilde eğleniriz fakat tatil dönüşü yoruluruz."

"Tatil bana deneyi ifade eder. Çünkü arkadaşlarımızla bir sürü malzemeyi karıştırıp sonucunda ne olacağın beklemeye benzer. Bir yandan heyecan bir yandan gerilim yaşarız."

\section{Finansal Alg1 Olarak Tatil Kategorisi}

Maddiyata dayanan değerlerle nitelendirilen bu kategoride üretilen metafor sayısı 7'dir ve toplamda üretilen metaforlar içerisinde $\% 3,58$ lik bir dilime sahiptir. Bu kategoride en fazla üretilen metaforlar; para $(\mathrm{f}=10)$, ekonomi $(\mathrm{f}=3)$, masraf $(\mathrm{f}=2)$ ve borç $(\mathrm{f}=2)$ metaforlarıdır. Aşağıda öğrencilerin bu kategoriyle ilgili metafor geliştirme nedenlerine yönelik görüşlerinden bazıları sunulmaktadır:

"Tatil bana parayı ifade eder. Çünkü çok para harcarım, iyi bir tatil için çok para gerekir, parayı harcayacak vakit vardır."

"Tatil bana ekonomiyi ifade eder. Çünkü tatil için gelen turistler döviz bırakıp ekonomiyi canlandırır, ülkeye katkı sağlar."

"Tatil bana altını ifade eder. Çünkü bulunmaz bir nimet gibidir."

"Tatil bana masrafı ifade eder. Çünkü bütün yıl çalışıp kazandı̆̆ın paranın yarısını tatilde harcarsın, otel konaklamaları, yiyecek-içecek fiyatları v.s. masraf yaratır." 


\section{Destinasyon (Yer) Algısı Olarak Tatil Kategorisi}

Tatil kavramının öğrenciler tarafından gidilecek yer olarak açıklandığı bu kategoride 7 adet metafor üretilmiştir. Toplamda üretilen metaforlar içerisinde \%1,43'lük orana sahip olan bu kategoride üretilen metaforlar; ülke ( $\mathrm{f}=2)$, Arizona ( $\mathrm{f}=1)$, Ayvalık ( $\mathrm{f}=1)$, Brezilya ( $\mathrm{f}=1)$, Kapadokya $(\mathrm{f}=1)$ ve Kutuplar $(\mathrm{f}=1)$ metaforlarıdır. Bu kategoride yer alan öğrencilerin ifadelerinden bazıları aşağıda sunulmuştur:

"Tatil bana kutupları ifade eder. Çünkü kayak yapmak ve şöminenin yanında sıcak çikolata içmek güzeldir."

"Tatil bana Arizona'yı ifade eder. Çünkü zor şartlarda kamp yapmak isterim."

"Tatil bana Kapadokya'yı ifade eder. Çünkü balonlara binip gökyüzüne yaklaşır, mutlu oluruz."

"Tatil bana Ayvalık'ı ifade eder. Çünkü benim için tatil demek; rakı balık Ayvalık'tır."

"Tatil bana Brezilya'yı ifade eder. Çünkü zamanımız bir karnaval tadında geçer."

\section{Turistik Alg1 Olarak Tatil Kategorisi}

Bu kategoride öğrenciler tatil kavramını turistik unsurlar ile ilişkilendirmişlerdir. Toplam 6 adet metafor üretilen kategori $\% 1,43$ 'lük bir orana sahiptir. Turizm ve otel $(\mathrm{f}=2)$, tatil köyü, otobüs, mola, festival ( $\mathrm{f}=1)$ metaforları üretilmiştir. Öğrencilerin bu metaforları geliştirmeye yönelik nedenleri aşağıda sunulmuştur:

"Tatil bana turizmi ifade eder. Çünkü tatil bir turizm faaliyetidir, tatiller sayesinde turizm sektörü gelişir ve daha aktif olur."

"Tatil bana oteli ifade eder. Çünkü tatil denilince ilk akla gelen yer oteldir."

"Tatil bana tatil köyünü ifade eder. Çünkü tatil köyü gibi huzur vericidir."

"Tatil bana molayı ifade eder. Çünkü hayatın içinde durup dinlenmektir."

"Tatil bana festivali ifade eder. Çünkü çeşitli sanatçıların katıldı̆̆ı etkinlikler, festivaller tatilde vazgeçilmez zevklerimdir."

\section{Tarihi ve Kültürel Algı Olarak Tatil Kategorisi}

Bu kategori, öğrencilerin "tatil" kavramını tarihi ve kültürel algılamalarından oluşan yorumlarına dayanmaktadır ve bu kategoride toplam 5 adet metafor üretilmiştir. Bu dilim, toplamda üretilen metaforlar içerisinde \%2,15'lik oranı oluşturmaktadır. Bu kategoride en fazla kültür ( $\mathrm{f}=5)$, tarih $(\mathrm{f}=3)$ ve gelenek-görenek ( $\mathrm{f}=2$ ) metaforları üretilmiştir. Öğrencilerin bu metaforları geliştirmeye yönelik görüşleri aşağıda özetlenmektedir:

"Tatil bana kültürü ifade eder. Çünkü insanlar gittikleri yerlerin kültürlerini öğrenir, farklı kültürlerde insanların kendi yaşam şekilleriyle diğer yaşam şekillerini kıyaslamasını să̆lar ve kültürel olarak gelişmeye yardımcı olur."

"Tatil bana tarihi ifade eder. Çünkü turizm sadece deniz kum güneş değildir. Gezilecek bir sürü tarihi yerler vardır, geçmişte, tarihte yaşananları yerinde görme olană̆ı sağlayarak şimdiki zamanı daha iyi anlamamiza yardımcı olur."

"Tatil bana gelenek görenek ifade eder. Çünkü farklı kültürlerdeki gelenek ve görenekleri tanıma şansımız olur." 


\section{SONUÇ ve ÖNERILER}

Yapılan araştırmanın sonucunda Turizm ve Otel İşletmeciliği bölümü önlisans öğrencilerinin tatil kavramına ilişkin olumlu yönde ve çok sayıda metafor geliştirdiği tespit edilmiştir. Bu sonuç, öğrencilerin tatil kavramına yönelik olumlu bir algıya sahip olduklarını göstermektedir. Ayrıca, öğrencilerin "tatil" kavramına ilişkin geliştirdikleri olumlu metaforlar, mezun olduklarında turizm sektöründe çalışırken turizmin geliştirilmesi, ulusal ve uluslararası düzeyde tanıtımının yapılması, ülke ekonomisine katkısının arttırılması gibi konularda üstlerine düşen görevi yerine getireceklerine işaret etmektedir. 170 metafor içerisinde, sadece 10 metafor "tatil" kavramina yönelik olumsuz bir nitelik taşımaktadır. Söz konusu bu metaforlar; sıkıntı (3), boşluk (3), yorgunluk (3), ölüm (2), borç (2), masraf (2), hüzün (1), stres (1), karanlık bir oda (1) ve fakirlik (1) metaforlarıdır. Olumsuz nitelik taşıyan bu metaforların toplam frekans içindeki oranı \%3,32'dir. Bayat'ın (2018) benzer çalışmasında ise bu oran daha düşüktür (\%2,43). Araştırmada üretilen bu olumsuz metaforların, öğrencilerin henüz ekonomik özgürlüğe sahip olmamalarından kaynaklandığı düşünülmektedir. İş hayatına atılıp, kendi ekonomik güçlerini ele aldıklarında tatile çıkmaları daha kolaylaşacak ve "tatil" kavramına bakış açıları da olumlu yönde değişebilecektir. "Tatil" kavramına olumlu algı ile yaklaşan turizm sektörü çalışanları turistlere daha kaliteli ve verimli hizmet sunabilirler. Bu konuda turizm işletmecisi yöneticilerine de büyük görevler düşmektedir. Yürütülecek işletme politikaları ile turizm sektörü çalışanlarının işlerine ve işletmeye bağlılıkları arttırılarak hizmet sunumunda daha aktif rol almaları sağlanabilir.

Turizm ve Otel İşletmeciliği bölümü önlisans öğrencileri toplamda 170 metafor geliştirmiştir. Öğrencilerin "tatil" kavramına ilişkin geliştirdikleri metaforlar, ortak özellikleri dikkate alınarak 11 farklı kavramsal kategori altında toplanmıştır. Araştırmanın bulgularına göre öğrencilerin "tatil" kavramına ilişkin algılarının önem sırasına göre klasik alg1, psikolojik algı, cansız ve soyut varlık algısı, gelişim aracı algıSı, sosyolojik algı, eylem algısı, canlı ve somut varlık algısı, finansal algı, tarihi ve kültürel algı, destinasyon (yer) algısı ve turistik algı olmak üzere 11 kategoride odaklandığı tespit edilmiştir. Önlisans öğrencilerinin turizm kavramına yönelik düşüncelerinin belirlenmesine yönelik yapılan bir çalışmada ise turizme yönelik toplam dokuz kategori tespit edilmiştir (Saçlık vd., 2016). Bu sonuç, katılımcıların tatil konusunda daha fazla metafor ürettiklerini ortaya koymaktadır. Tatil kavramı en fazla klasik algı kategorisi altında "dinlenme", psikolojik algı kategorisi altında "huzur", cansız ve soyut varlık kategorisi altında "dinginlik", gelişim aracı algısı kategorisi altında "yeni insanları tanımak", sosyolojik algı kategorisi altında "aile", eylem algısı kategorisi altında "çalışmak", canlı ve somut varlık kategorisi altında "kum saati", finansal algı kategorisi altında "para", tarihi ve kültürel algı kategorisi altında "kültür", destinasyon (yer) algısı kategorisi altında "ülke" ve turistik algı kategorisi altında "turizm" ve "otel" kavramlarına benzetilmiştir.

Metaforlara ilişkin gerekçelerde genel olarak tatil kavramının dünyayı güzelleştiren, yeni yerleri ve yeni insanları keşfetmeye olanak sağlayan, insanları motive eden, ekonomiyi canlandıran ve aile bağlarını kuvvetlendiren bir kavram olarak ifade edildiği tespit edilmiştir. Ayrıca Turizm ve Otel İşletmeciliği bölümü önlisans öğrencilerinin 170 farklı metafor geliştirmesi tatil kavramı hakkında çok geniş görüşlere sahip olduklarını göstermektedir. Turizm sektöründe ara eleman olarak yetiştirilen öğrencilerin tatil kavramına ilişkin farkındalıklarının yüksek olması, mesleklerini yürütürken daha bilinçli hareket edeceklerinin ve başarılı olacaklarının bir göstergesidir. Önlisans öğrencileri, turizmin geliştirilmesi ve milli değerlerimizin tanıtılması konusunda aktif rol oynamaktadır. Bu nedenle, tatil kavramına ilişkin bilinçlerinin gelişmiş olması, turizm sektöründe verilecek hizmeti kaliteli hale getirecek, işletmelerin gücünü arttıracak ve alternatif turizm olanaklarına katkı sağlayacaktır. 
Araştırmada önlisans öğrencilerinin tatil kavramına yönelik olarak en fazla klasik $(\% 35,48)$ ve psikolojik $(\% 27,42)$ algıya sahip oldukları tespit edilmiştir. Buna karşın tarihi ve kültürel $(\% 2,15)$, destinasyon $(\% 1,43)$ ve turistik $(\% 1,43)$ algı düzeyleri oldukça düşüktür. Konuya yönelik benzer bir çalışmada (Özder vd., 2012), öğrencilerin turizm kavramı ilişkin klasik turizm anlayışının yanı sıra, tarihi ve kültürü de ön plana çıkaran metaforlar ürettikleri ortaya çıkmıştır. Ancak araştırma sonuçları, öğrencilerin tatil kavramını turizm, tarih ve kültür ile ilişkilendirme bakış açılarının oldukça düşük olduğunu göstermektedir. Bu sonuçlar, Turizm ve Otel İşletmeciliği bölümü önlisans eğitiminde turizmin genel yapısı, tarihi ve kültürel etkileşimler, manevi değerlere sahip çıkma bilinci ve farkındalığı üzerinde daha fazla durulması gerekliliği ortaya koymaktadır. Turizm ve Otel İşletmeciliği bölümü olarak önlisans eğitimi veren kurumlara Genel Turizm, Turizm Coğrafyası, Turizm Sosyolojisi, Meslek Etiği, Davranış Bilimleri gibi derslerde öğrencilerin farkındalık düzeylerinin arttırılmasına ilişkin eğitime daha fazla ağırlık vermeleri önerilebilir.

İlgili alanyazında turizm kavramına ilişkin metaforların belirlenmesine yönelik bir çalışmaya rastlanmış (Saçlık vd, 2016), ancak turizm kavramının ana unsuru olan tatil kavramına yönelik bir metafor çalışmasına rastlanmamıştır. Araştırmanın çalışma grubunu önlisans düzeyinde Turizm ve Otel İşletmeciliği eğitimi veren Balıkesir Üniversitesi Balıkesir Meslek Yüksekokulu ve Sındırgı Meslek Yüksekokulu öğrencileri oluşturmaktadır. Gelecek araştırmalarda turizm alanında öğrenim gören lisans ve lisansüstü öğrencilerin, turizm akademisyenlerinin, turizm çalışanlarının ve profesyonellerinin tatil kavramına yönelik algıları metafor analizi ile incelenebilir. Kavrama yönelik bilinç ve farkındalık düzeyleri tespit edilebilir. Bu nedenle çalışmadan elde edilen bulguların farklı akademik çalışmalara öncülük edebileceği ve veri kaynağı sağlayabileceği düşünülmektedir.

\section{KAYNAKÇA}

Aladağ, S. ve Kuzgun, M. P. (2015). Sınıf öğretmeni adaylarının "değer" kavramına ilişkin metaforik algıları. Sakarya Üniversitesi Ĕ̆itim Fakültesi Dergisi, 29, 163-193.

Altun, T. ve Camadan, F. (2013). Rehber öğretmenlerin rehber öğretmen (psikolojik danışman) kavramına ilişkin algılarının metafor analizi yoluyla incelenmesi. Kastamonu Ĕ̆itim Dergisi, 21(3), 883-918.

Aslan, G. (2015). Öğretmen adaylarının toplumsal cinsiyet algılarına ilişkin metaforik bir çözümleme. Eğitim ve Bilim, 40(181), 1300-1337.

Ateş, M. ve Karatepe, A. (2013). Üniversite öğrencilerinin "küresel 1sınma" kavramına ilişkin algılarının metaforlar yardımıyla analizi. Marmara Coğrafya Dergisi, 27(Ocak), 221-241.

Aydın, F. (2011). Üniversite öğrencilerinin "çevre" kavramına ilişkin metaforik algıları. Doğu Coğrafya Dergisi, 16(26), 25-44.

Ayyıldız, T. (2016). Üniversite öğrencilerinin dans kavramına yönelik metaforik algılarının analizi. Gaziantep Üniversitesi Spor Bilimleri Dergisi, 1(2), 13-25.

Babacan, E. (2014). AGSL öğrencilerinin müzik kavramına ilişkin algıları: Metafor analizi. Eğitim ve Öğretim Araştırmaları Dergisi, 3(1), 124-132.

Banim, M., Guy, A. and Gillen, K. (2015). It's like planet holiday"-Women's dressed self presentation on holiday. Fashion Theory, 9(4), 425-444.

Baş, G. ve Kıvılcım, Z.S. (2019). Türkiye'de öğrencilerin merkezi sistem sınavları ile ilgili algıları: Bir metafor analizi çalışması. Ĕ̆itimde Nitel Araştırmalar Dergisi, 7(2), 639-667. 
Başarır, F. ve Sarı, M. (2015). Kadın akademisyenlerin "kadın akademisyen olma"ya ilişkin algılarının metaforlar yoluyla incelenmesi. Yükseköğretim ve Bilim Dergisi, 5(1), 41-51.

Bayat, G. (2018). Ağrı Dağı'nın Kırsal Turizm Potansiyeli ve Iğdır Halkı'nın Ağrı Dağı ile İlgili Algıları. TURAN-SAM Uluslararası Bilimsel Hakemli Dergisi, 10(39), 40-48.

Bilgen, N., Şahin, M. H. ve Karatepe, A. (2014). Meslek lisesi ve meslek yüksekokulu öğrencilerinin termal turizm kavramına yönelik düşüncelerinin metaforlar yolu ile analizi. SDU International Journal of Education Sciences, 1(2), 80-87.

Bos, L., McCabe, S. and Johnson, S. (2015). Learning never goes on holiday: an exploration of social tourism as a context for experiential learning. Current Issues in Tourism, 18(9), 859-875.

Boz, D. ve Duran, C. (2018). Girişimcilik dersi alan İ̈BF öğrencilerinin girişimcilik algılarının metaforlar aracılı̆̆ıyla analizi. Girişimcilik ve Kalkınma Dergisi, 13(2), 110-123.

Bozdoğan, Y. K. ve Sünbül, A. M. (2016). Ortaokul 7. sınıf öğrencilerinin "müze" kavramına ilişkin geliştirdikleri metaforlar. Sakarya Üniversitesi Eğitim Fakültesi Dergisi, 31, 107-127.

Cerit, Y. (2008). Öğretmen kavramı ile ilgili metaforlara ilişkin öğrenci, öğretmen ve yöneticilerin görüşleri. Türk Eğitim Bilimleri Dergisi, 6(4), 693-712.

Chen, X., Mak, B. and Calder, I. (2020). The guimi holidays of young Chinese women: Evidence from cyber communities. Journal of China Tourism Research, 17(2), 230-248.

Cocco, E. (2010). Performing maritime imperial legacies: Tourism and cosmopolitanism in Odessa and Trieste. Anthropoligical Notebooks, 16(1), 41-61.

Çakıcı, C. ve İyitoğlu, V. (2012). Tatil karalarında aile üyelerinin rolü: Antalya ilinde tatil yapan aileler üzerine bir araştırma. Ç.Ü. Sosyal Bilimler Enstitüsü Dergisi, 21(1), 117-134.

Çapan, B. E. (2010). Öğretmen adaylarının üstün yetenekli öğrencilere ilişkin metaforik algıları. Uluslararası Sosyal Araştırmalar Dergisi, 3(12), 14-154.

Çelik, T. ve Arı, G. S. (2017). Bankalarda örgüt kültürünün belirlenmesinde alternatif bir yöntem olarak metafor analizi. Eskişehir Osmangazi Üniversitesi İ̈BF Dergisi, 12(1), 31-64.

Dilek, N.K., Dilek, S. E. ve Gümüş, M. (2016). Otel çalışanlarının turizm ve barış ilişkisine yönelik metaforik algıları. Batman Üniversitesi Yaşam Bilimleri Dergisi, 6, (2/1), 1-15.

Doğan, D. (2014). Öğretmen adaylarının perspektifinden okul kavramının metaforlarla analizi. Kuramsal Eğitim Bilim Dergisi, 7(3), 361-382.

Doğan, Y. (2017). Ortaokul öğrencilerinin çevre kavramına ilişkin sezgisel algıları: Bir metafor analizi. Ahi Evran Üniversitesi Kırşehir Eğitim Fakültesi Dergisi, 18(1), 721-740.

Doğanay, H. (2001). Türkiye Turizm Coğrafyası. Konya: Çizgi Kitabevi Yayınları.

Döş, İ. (2010). Aday öğretmenlerin müfettişlik kavramına ilişkin metafor algıları. Gaziantep Üniversitesi Sosyal Bilimler Dergisi, 9(3), 607-629.

Ekici, G. (2016). Biyoloji öğretmeni adaylarının mikroskop kavramına ilişkin algılarının belirlenmesi: Bir metafor analizi çalışması. Ahi Evran Üniversitesi Kırşehir Ĕ̆itim Fakültesi Dergisi, 17(1), 615-636.

Ekici, G. ve Akdeniz, H. (2018). Lise öğrencilerinin "ödev" kavramına ilişkin metaforik algılarının incelenmesi. Bayburt Ĕ̆gitim Fakültesi Dergisi, 13(25), 135-162.

Eren, F., Çelik, İ. ve Aktürk, A. O. (2014). Ortaokul öğrencilerinin facebook algısı: Bir metafor analizi. Kastamonu Ĕ̆itim Dergisi, 22(2), 635-648. 
Gardiner, S., Grace, D. and King, C. (2015). Is the Australian domestic holiday a thing of the past? Understanding baby boomer, generation $\mathrm{X}$ and generation $\mathrm{Y}$ perceptions and attitude to domestic and international holidays. Journal of Vacation Marketing, 21(4), 336-350.

Geçit, Y. ve Gençer, G. (2011). Sınıf öğretmenliği 1.sınıf öğrencilerinin coğrafya algılarının metafor yoluyla belirlenmesi (Rize üniversitesi örneği). Marmara Coğrafya Dergisi, 23, Ocak, 1-19.

Göçer, A. ve Aktürk, Y. (2015). İlk ve ortaokul öğretmenlerinin öğretmen kılavuz kitabına yönelik algıları: Metafor analizi. Uluslararası Türk Ĕ̆itim Bilimleri Dergisi, Nisan, 186-199.

Gömleksiz, M.N., Kan, A.Ü. ve Öner, Ü. (2012). İlköğretim öğrencilerinin sosyal bilgiler dersine ilişkin metaforik algıları. Erzincan Üniversitesi Ĕ̆itim Fakültesi Dergisi, 14(2), 419-436.

Gram, M. (2005). Family holidays. A qualitative analysis of family holiday experiences. Scandinavian Journal of Hospitality and Tourism, 5(1), 2-22.

Hacıfazlığlu, Ö., Karadeniz, Ş. ve Dalgıç, G. (2011). Okul yöneticilerinin teknoloji liderliğine ilişkin algıları: Metafor analizi örneği. Eğitim Bilimleri Araştırmaları Dergisi, 1(1), 97-121.

Hosany, S. and Gilbert, D. (2010). Measuring tourists' emotional experiences toward hedonic holiday destinations. Journal of Travel Research, 49 (4), 513-526.

Jones, P.H. and Blackburn, A. (2007). Understanding the relationship between holiday taking and sef-assessed health: an exploratory study of senior tourism. International Journal of Consumer Studies, 31, 509-516.

Kahyaoğlu, M. ve Kırıktaş, H. (2016). Ortaöğretim ve üniversite öğrencilerinin "doğa" kavramına ilişkin algılarının metafor analizi yoluyla incelenmesi. Marmara Coğrafya Dergisi, 33(Ocak), 58-76.

Karaçam, S. ve Aydın, F. (2014). Ortaokul öğrencilerinin teknoloji kavramına ilişkin algılarının metafor analizi. Gaziantep University Journal of Social Sciences, 13(2), 545-572.

Kaya, M. F. (2014). Sosyal bilgiler öğretmen adaylarının "küresel ısınma" kavramına yönelik metafor algıları. Doğu Coğrafya Dergisi, 18 (29), 117-134.

Kaya, M. F. (2014). Sosyal bilgiler öğretmen adaylarının çevre sorunlarına ilişkin algıları. Metafor analizi örneği. Electronic Turkish Studies, 9(2), 917-931.

Kervankıran, İ. ve Özdemir, M.A. (2013). Turizm yönüyle gelişmekte olan Afyonkarahisar ilinde turist algısı üzerine bir araştırma. Marmara Coğrafya Dergisi, 27, Ocak, 117-142.

Kintsch, W. (2000). Metaphor comprehension: A computational theory. Psychonomic Bulletin $\mathcal{E}$ Review, 7(2), 257-266.

Korkut, A.ve Keskin, İ. (2016). Üniversite öğrencilerinin kariyer algıları: Metaforik bir analiz çalışması. Mustafa Kemal Üniversitesi Sosyal Bilimler Enstitüsü Dergisi, 13(33), 194-211.

Köroğlu, Ö, Yıldırım, H. U. ve Avcıkurt, C. (2018). Kültürel miras kavramına ilişkin algıların metafor analizi yoluyla incelenmesi. Turizm Akademik Dergisi, 5(1), 98-113.

Lakoff, G. and Johnson, M. (2005). Metaforlar Hayat Anlam ve Dil. (Çeviren: Gökhan Yavuz Demir). İstanbul: Paradigma Yayıncilık.

Larsen, J.R.K. (2013). Familiy flow: the pleasures of "being together" in a holiday home. Scandinavian Journal of Hospitality and Tourism, 13(3), 153-174.

Özbaş, B. Ç. ve Aktekin, S. (2013). Tarih öğretmen adaylarının tarih öğretmenliğine ilişkin inançlarının metafor analizi yoluyla incelenmesi. Eğitimde Kuram ve Uygulama, 9(3), 211-228. 
Özder, A., Kaya, H. ve Ünlü, M. (2012). Ortaöğretim öğrencilerinin "turizm" kavramı ile ilgili geliştirdikleri metaforların analiz örneği. Marmara Coğrafya Dergisi, Ocak, 18-31.

Özer, S. ve Türel, Y. K. (2015). Bilişim Teknolojileri öğretmen adaylarının e-kitap ve etkileşimli ekitap kavramına ilişkin metaforik algıları. Turkish Online Journal of Qualitative Inqury, 6(2), 1-23.

Pesen, A. (2015). Ebeveynlerin "çocuk" kavramına yükledikleri metaforlar. Turkish Studies, 10(15), $731-748$.

Polat, S., Apak, Ö. ve Akdağ, M. (2013). Sınıf öğretmeni adaylarının akademisyen kavramına ilişkin algılarının metafor analizi. İnönü Üniversitesi Eğitim Fakültesi Dergisi, 14(2), 57-78.

Saban, A. (2004). Giriş düzeyindeki sınıf öğretmeni adaylarının "öğretmen" kavramına ilişkin ileri sürdükleri metaforlar. Türk Eğitim Bilimleri Dergisi, 2(2), 131-155.

Saban, A. (2008). Okula ilişkin metaforlar. Kuram ve Uygulamada Eğitim Yönetimi, 55, 459-496.

Saban, A. (2009). Öğretmen adaylarının öğrenci kavramına ilişkin sahip oldukları zihinsel imgeler. Türk Eğitim Bilimleri Dergisi, 7(2), 281-326.

Saçıllk, M.Y., Çevik, S. ve Özkan, Ç. (2016). Turizm ve otel işletmeciliği bölümü önlisans öğrencilerinin "turizm" olgusuna ilişkin metaforik algıları. Akademik Bakış Dergisi, 53, 84-103.

Soysal, D. ve Afacan, Ö. (2012). İlköğretim öğrencilerinin "fen ve teknoloji" dersi ve "fen ve teknoloji öğretmeni" kavramlarına yönelik metafor durumları. Mustafa Kemal Üniversitesi Sosyal Bilimler Enstitüsü Dergisi, 9(19), 287-306.

Sönmez, V. ve Alacapınar, F. G. (2011). Bilimsel Araştırma Yöntemleri. Ankara: Anı Yayıncılık.

Şahin, Ş. ve Baturay, M. H. (2013). Ortaöğretim öğrencilerinin internet kavramına ilişkin algılarının değerlendirilmesi: Bir metafor analizi çalışması. Kastamonu Üniversitesi Kastamonu Eğitim Dergisi, 21(1), 177-192.

Şenel, T. ve Aslan, O. (2014). Okul öncesi öğretmen adaylarının bilim ve bilim insanı kavramlarına ilişkin metaforik algıları. Mersin Üniversitesi Eğitim Fakültesi Dergisi, 10(2), 76-95.

Tok, E. (2018). Okul öncesi öğretmen adaylarının oyuna ilişkin algıları: Metafor analizi örneği. Kastamonu Ĕ̆itim Dergisi, 26(2), 599-611.

Uğurlu, Z. (2018). Öğretmen adaylarının üniversite kavramına ilişkin algılarının metafor analizi. Çă̆daş Yönetim Bilimleri Dergisi, 1(5), 80-93.

Voase, R. (2018). Holidays under the hegemony of hiper-connectivity: getting away, but unable to escape. Leisure Studies, 37(4), 384-395.

Wells, Ş. Y. (2015). Görsel sanatlar öğretmeni adaylarının öğretmen ve sanatçı algısına ilişkin metafor analizi. Hacettepe Üniversitesi Ĕ̆itim Fakültesi Dergisi, 30(3), 160-175.

Woodside, A. and King, R. (2001). An updated model of travel and tourism purchase consumption systems. Journal of Travel ETourism Marketing, 10(1), 3-26.

Yıldırım, A. ve Şimşek, H. (2011). Sosyal Bilimlerde Nitel Araştırma Yöntemleri. (8. Basım). Ankara: Seçkin Yayıncılık.

Yob, I. M. (2003). Thinking constructively with metaphors. Studies in Philosophy and Education, 22, $127-138$

Zembat, R., Tunçeli, H. İ. ve Akşin, E. (2015). Okul öncesi öğretmen adaylarının "okul yöneticisi" kavramına ilişkin algılarına yönelik metafor çalışması. Hacettepe University Faculty of Health Sciences Journal, 1(2), 446-459. 